\title{
Capital inflows, exchange rate and agricultural output in Nigeria
}

\author{
Fredrick Ikpesu ${ }^{1 *}$ and Abraham Emmanuel Okpe ${ }^{2}$
}

\begin{abstract}
The study applied the autoregressive distributed lag (ARDL) technique in investigating the effect of capital inflows and exchange rate on agricultural output in Nigeria between the periods 1981 and 2016. The technique was selected because the variables are integrated at both $1(1)$ and $1(0)$ and the sample size is considerably small. Variables used in the study are agricultural output (AO), private capital inflow (PRCI), public capital inflow (PUBCI), investment (INV), labor $(L)$ and real effective exchange rate. Findings from the empirical research revealed that the variables are cointegrated. The research outcome also indicates that in the short run and long run, private capital inflow and public capital inflow positively affect the country agricultural output. The study also revealed that exchange rate depreciation would cause agricultural output to decline in the short and long run. Based on the research findings, it is recommended that the government should create an enabling and conducive environment to attract more inflows of foreign capital into the country to boost the agricultural output. Also, monetary authority should ensure the stability of the country's exchange rate (Naira) since exchange rate depreciation affects agricultural output negatively. Furthermore, there is the need for the harmonization of foreign capital inflow policy and monetary policy by the government, taking into consideration the optimal level of capital inflow that will not have a detrimental effect on exchange rate so as to ensure sustainable growth in agricultural output.
\end{abstract}

Keywords: Capital inflows, Agricultural output, Exchange rate, ARDL, Nigeria

JEL Classification: F1, Q1, C3

\section{Introduction}

Prior to 1960, when the nation got its independence, agriculture was at the forefront of the Nigerian economy, contributing among others in the provision of food, raw materials for industry and employment opportunities for the populace. These have, however, dwindled significantly following the discovery of oil in 1956. Iddrisu et al. [20] documented that agricultural sector growth would drive growth in the economy because the sector is a major employment of labor and contributes a lot to GDP of many sub-Saharan Africa (SSA) economies.

The key problem facing the sector in the country is lack of adequate finance needed in revitalizing the sector $[4,7]$. Likewise, Msuya [28], Abro et al. [2], Christiaensen and

\footnotetext{
*Correspondence: fikpesu@pau.edu.ng

1 Pan-Atlantic University, Km 52, Lekki-Epe Expressway, Ibeju-Lekki, Lagos, Nigeria

Full list of author information is available at the end of the article
}

Todo [11] argue that to reduce poverty and ensure sustainability in developing economies, there is the need for the sector to develop. Research findings from [23, 31, 36] revealed that in most African economies (Nigerian inclusive), there is a savings-investment gap and also foreign exchange gap which has hindered developing economies in embarking on a developmental project that will improve citizens' welfare. These gaps necessitated the deployment of diverse strategic reforms such as privatization, investment policy, tax policy, trade liberalization policy among others in the SSA in a bid to attract and sustain the inflow of foreign capital capable of enhancing agricultural output to ensure food security and robust economy.

However, due to the poor internally generated revenue in the country to sustain agricultural output, the need to hinge on foreign capital inflow as an alternative source of funding the sector became necessary as this will act as a catalyst in stimulating economy development and growth thus resonating with $[8,27]$, that the impact of capital 
inflow in stimulating the national economy is the most reliable path to sustainability.

Based on Food and Agriculture Organization of the United Nations (FAO) estimate, less developed economies need USD 83 billion yearly investments to meet food requirement [19]. However, these developing economies do not have the capacity to meet such yearly investment, due to the reduction in government spending on agriculture to $7 \%$, insufficient commercial loan (less than 10\%) to agriculture [19]. Hence, the call for foreign capital inflows to boost agricultural productivity in those countries.

Studies have also shown that appreciation of exchange rate is harmful to export, while depreciation of exchange rate not only increase the supply of export but also boost the diversification of export [32, 33, 38]. Empirical evidence has shown that capital inflows can cause depreciation of a country currency $[8,21]$ which in turn affects agricultural output negatively because the importation of modern farm equipment and tools needed to increase agricultural output becomes more expensive [20].

Figure 1 depicts the graph of capital inflow, agricultural output, and growth. During the pre-democracy era (before 1999), the sector contribution to GDP has been evidently poor due to the neglect of the sector over-time as a result of the discovery of oil. However, the democracy era (1999 to date) has focused attention on the sector and that has fostered its contribution to national output. More so, because of the implementation of the country's indigenization policy in 1970s, foreign participation in local businesses was undermined during the pre-democracy era but with the inception of the democratic government, the investment climate became more favorable in attracting foreign capital inflows. Hence, as evident in the democratic period, capital inflows have supported the growth of agricultural output and consequently the growth of the economy; although, there is need for more effort both in terms of policy measures and infrastructural support.

Against the foregoing background, this study examines the effect of capital inflows, and exchange rate on agricultural output in Nigeria in a bid to answer the research question whether capital inflows and exchange rate affect agricultural output in the country. This research paper differs from existing literature because majority of the empirical work done in this area considers only the private flow component of capital inflow (foreign direct investment) and its effect on agricultural output [12, 16, 32, 40, $41,43]$ while ignoring the public flow component of capital inflows thus providing the motivation for the study. Also, by investigating the effect of public capital inflows alongside private capital inflows, and exchange rate on the agricultural output in the country using an ARDL technique, the study has filled the gap in the literature. The significant of the study is that the findings from the study will serve as a guide to government and policymakers in designing and implementing appropriate policy in the short run and also in the long run in relation to capital inflows (private and public inflows), and exchange rate so as to achieve sustainable growth in agricultural output.

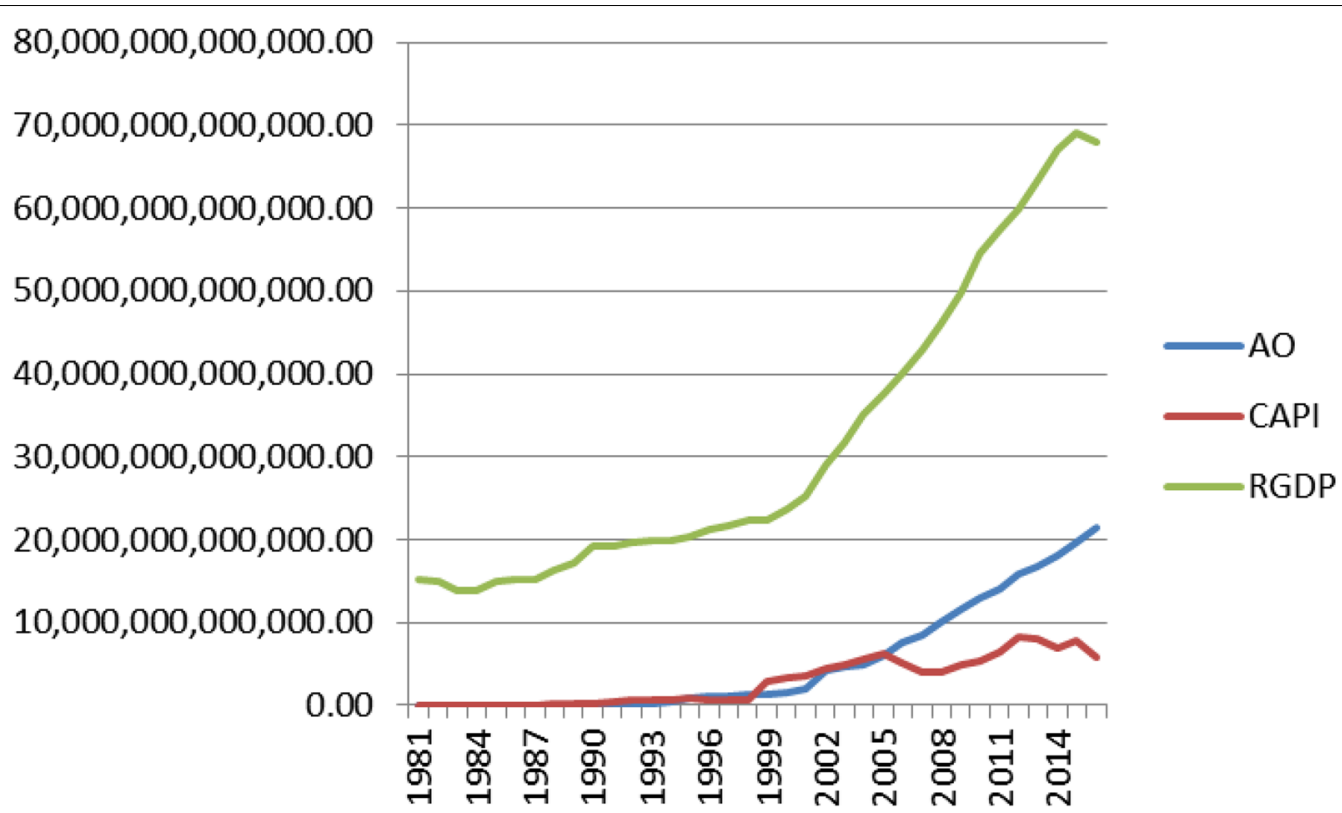

Fig. 1 Trend of capital inflow, agricultural output and growth (Source: Authors'2018) 
Consequently, the study contributes to the literature in several ways. First, the study decomposes the capital inflows into private flows and public flows when investigating the effect of capital inflows and exchange rate on agricultural output, unlike past studies that concentrated on private capital inflows especially FDI. Second, the study explores the relationship between capital inflow, exchange rate and agricultural output in the short and long run. Third, this study contributes new findings on the link between capital inflows, exchange rate, and agricultural output specifically, in the area of the effect of capital inflows and exchange rate on Nigeria agricultural output.

The remainder of the research paper is divided into the following sections. Section two examines the related literature. Section three explains the methodology adopted in the study. Section four presents and discusses the outcome of the research findings. The final section presents the conclusion of the study.

\section{Review of theory an empirical literature}

According to the endogenous and neoclassical growth model, capital inflows (Private and Public inflows) enhance the growth of the economy. Also, according to the two-gap model, capital inflows bridge the savings and foreign exchange gap that exist in a developing economy. The saving gap is the gap between savings and investment; while the foreign exchange gap is the gap between import and export. Majority of the developing economy relies on the inflow of foreign capital to enhance agricultural output in a bid to eradicate/reduce poverty, provide employment opportunities and ensure sustainability in the agricultural sector. The neoclassical growth theory postulates that the inflow of foreign capital provides the developing economies an opportunity to be able to acquire the required technology that will enhance and promote productivity, stimulate growth and ensure sustainable development in the agricultural sector [3, 30, 34, 37, 42].

Several studies have shown that the inflow of foreign capital has positively influenced the growth of agricultural output in developing economies. Findings by Zingwena [43] showed that FDI has positively affected the growth of agricultural output in Zimbabwe. Likewise, Gameli Djokoto et al. [17] also confirmed that FDI exerts a positive effect on Ghana agricultural output. Other studies conducted have also shown that FDI plays a significant role in terms of increasing welfare and reducing unemployment problem in a country, and hence advocate for the need of FDI to be directed to the agricultural sector of less developed countries [10, 28,35].

Several other studies have been conducted in Nigeria to examine the link between capital flows and agricultural output. Research study in Nigeria conducted by Akpokodje and Omojmite [6], Ajuwon and Ogwumike
[5], Oloyede [32], Yusuf [40], Kareem et al. [24], Yusuff et al. [41] and Eke (2016); all showed that FDI has positively influenced the growth of the agricultural sector in the economy. However, despite the positive impacts of capital inflows on agricultural output, some scholars still have opposing views based on their research finding. Larson and Vogel [25], Massoud [26], Djokoto [12, 13], Iddrisu et al. [20], Epaphra [15], Epaphra and Mwakalasya [16]; documented that the inflow of foreign capital affects agricultural output negatively.

Furthermore, on the link between exchange rate and agricultural output, Oyinbo et al. [33] concluded that that exchange rate affects the agricultural share of GDP negatively. Wondemu and Potts [38] research findings revealed that exchange rate appreciation affects export, while exchange rate depreciation raised the supply of export and boost the diversification of export. Abdullahi [1] research findings indicate that agricultural output positively responds to exchange rate, inflation and interest rate in the long run. Yaqub [39] using a two-stage least square technique showed that while exchange rate affects fishery and crop output negatively, it affects forestry and livestock positively. Iddrisu et al. [20] concluded that the depreciation of the country currency (cedi) negatively affects Ghana agricultural output.

\section{Theoretical framework}

The study adopts the conventional neo-classical growth production function. The neo-classical production function links the aggregate output in period $t$ with inputs or factors of production.

Expressing the neo-classical production function in the form of Cobb-Douglas production

$$
Y_{t}=A_{t} K_{t}^{\alpha} L_{t}^{\beta},
$$

where $Y_{t}$ represents agricultural output (AO) at time $t$, while $A_{t}$ represents total factor productivity, $K_{t}$ capital stock (domestic investment) and $L_{t}$ labor stock, $\alpha$ and $\beta$ are the output elasticities of capital and labor, respectively.

According to the endogenous and neoclassical growth model, capital inflow (Private and Public inflows) operates through the total factor productivity $(A)$ since capital inflows can stimulate growth provided there is an increasing return to production that would enhance output [42]. Hence, total factor productivity is a function of capital inflow.

$$
A_{t}=f(\mathrm{CAPI})
$$

Thus, combining Eqs. 1 and 2, the Cobb-Douglas production function is expressed as 


$$
Y_{t}=\mathrm{CAPI}_{t} K_{t}^{\alpha} L_{t}^{\beta}
$$

where CAPI is capital inflows (Private and Public inflows).

Following similar studies, additional variable such as real effective exchange rate was employed to capture the efficiency of economic activity. Empirical studies have shown that real effective exchange rate affects agricultural output [1, 20, 33, 38]. Hence, the Cobb-Douglas production function is modified and, thus, expressed as

$$
Y_{t}=\mathrm{CAPI}_{t} K_{t}^{\alpha} L_{t}^{\beta} \mathrm{REXR}_{t}
$$

Decomposing capital inflow into private and public capital inflows, the study expressed two models:

$$
\begin{aligned}
\log Y_{t}= & \alpha_{0}+\alpha_{1} \log \text { PRCI }+\alpha_{2} \log K \\
& +\alpha_{3} \log L+\alpha_{4} \text { REXR }+\mu_{t}, \\
\log Y_{t}= & \alpha_{0}+\alpha_{1} \log \text { PUBCI }+\alpha_{2} \log K \\
& +\alpha_{3} \log L+\alpha_{4} \text { REXR }+\mu_{t},
\end{aligned}
$$

where $Y$ is the Agricultural output; PRCI is the Private capital inflow; PUBCI is the Public capital inflow; $K$ is the Domestic investment; $L$ is the Labor force; REXR is the Real effective exchange rate; $\mu$ is the Error term.

In summary, the review of the literature has shown a mixed result. While some researchers claimed that capital inflows influence agricultural output positively [17, $24,32,40,43]$, others have divergent views that capital inflows exert a negative effect on agricultural output [13, $14,15,26]$. Also, most of the studies focused on the effect of FDI on agricultural output thus ignoring other components of private and public capital inflows. In addition, the effect of capital inflows and exchange rate on agricultural output, however, remains open to question. Hence, this study fills the gap in the literature by investigating the effect of both private and public capital inflows, and exchange rate on agricultural output in Nigeria using an ARDL technique.

\section{Data and methodology \\ Data}

This study utilizes time series data covering the period 1981-2016. The data have been obtained from different sources, including Central Bank of Nigeria (CBN) statistical bulletin and World development indicator (WDI), a publication of World Bank. The variables employed in the study are agricultural output, labor force, domestic investment, real effective exchange rate and capital inflows (private capital inflows (foreign direct Investment, workers remittance, and portfolio investment) and public capital inflow (foreign borrowing, and official development assistance). Data on agricultural output and real exchange rate were collected from Central Bank of Nigeria (CBN) statistical bulletin; while data on domestic investment and labor force were collected from World development indicator (WDI), a publication of World Bank. The data on capital inflow were collected from WDI and CBN statistical bulletin.

\section{Autoregressive distributed lag (ARDL) model}

The study employed the ARDL approach in investigating the effect of capital inflows (Private and Public flow) and exchange rate on agricultural output in Nigeria. The technique was selected because the variables are integrated at both $1(1)$ and $1(0)$ and the sample size is considerably small.

The study employed two ARDL models based on the aims of the study. The first aim is to investigate the effect of private capital inflow and exchange rate on agricultural output, while the second aim is to examine the effect of public capital inflow and exchange rate on agricultural output. To address the first objective, the ARDL model is expressed as follows:

$$
\begin{aligned}
\Delta \log (\mathrm{AO})_{t} \\
=\alpha_{0}+\sum_{i=0}^{n} \alpha_{1} \Delta \log (\mathrm{AO})_{t-1}+\sum_{i=0}^{n} \alpha_{2} \Delta \log (\mathrm{PRCI})_{t-1} \\
+\sum_{i=0}^{n} \alpha_{3} \log (K)_{t-1}+\sum_{i=0}^{n} \alpha_{4} \Delta \log (L)_{t-1} \\
+\sum_{i=0}^{n} \alpha_{5} \Delta \log (\mathrm{REXR})_{t-1}+\beta_{1} \Delta \log (\mathrm{AO})_{t-1} \\
+\beta_{2} \Delta \log (\mathrm{PRCI})_{t-1}+\beta_{3} \Delta \log (K)_{t-1} \\
+\beta_{4} \Delta \log (L)_{t-1}+\beta_{5} \Delta \log (\mathrm{REXR})_{t-1} \\
+\mathrm{ECT}_{t-1}+\mu_{t}
\end{aligned}
$$

To address the second objective, the ARDL model is expressed as follows:

$$
\begin{aligned}
\Delta & \log (\mathrm{AO})_{t} \\
= & \alpha_{0}+\sum_{i=0}^{n} \alpha_{1} \Delta \log (\mathrm{AO})_{t-1}+\sum_{i=0}^{n} \alpha_{2} \Delta \log (\mathrm{PUBCI})_{t-1} \\
& +\sum_{i=0}^{n} \alpha_{3} \log (K)_{t-1}+\sum_{i=0}^{n} \alpha_{4} \Delta \log (L)_{t-1} \\
& +\sum_{i=0}^{n} \alpha_{5} \Delta \log (\mathrm{REXR})_{t-1}+\beta_{1} \Delta \log (\mathrm{AO})_{t-1} \\
& +\beta_{2} \Delta \log (\mathrm{PUBCI})_{t-1}+\beta_{3} \Delta \log (K)_{t-1} \\
& +\beta_{4} \Delta \log (L)_{t-1}+\beta_{5} \Delta \log (\mathrm{REXR})_{t-1} \\
& +\mathrm{ECT}_{t-1}+\mu_{t},
\end{aligned}
$$


where $\log (\mathrm{AO})$ is the Natural log of Agricultural Output; $\log (\mathrm{PRCI})$ is the Natural log of Private Capital Inflows; $\log$ (PUBCI) is the Natural log of Public Capital Inflows; $\log (K)$ is the Natural log of Domestic Investment; log $(L)$ is the Natural log of Labor Force; log (REXR) is the Natural log of Real Effective Exchange rate; $\alpha_{0}$ is the drift component; $n$ is the maximum lag length; $\Delta$ is the first difference operator; $\mu_{t}$ is the white noise; $t$ is the time; ECT is the Error correction time

\section{Estimation technique Stationarity test}

In testing for the stationarity and order of integration of the variables, the study employed the Kwiatkowski, Phillips, Schmidt, and Shin (KPSS) test. The choice of KPSS test is because it is more powerful unit root test when compared to the Augmented Dickey-Fuller (ADF) and Philip Peron test. The study also employed the use of Bai-Perron test to capture the structural break in the variable. Dummy variable will be included in the model if a structural break occurs especially in the dependent variable. The period before the structural break will be assigned 0 , while the period after the structural break will be assigned 1 .

\section{Cointegration test}

The study used the ARDL bound test in a bid to ascertain the cointegration of the variables. According to Nkoro and Uko [29], Bentzen and Engsted [9], Ghatak and Siddiki [18], the ARDL bound test has the following advantages over the Johansen and Juselius [22] co-integration technique.

i. It is used when variables are integrated in a different order, 1(0), 1(1) or a mix of both.

ii. It is used to analyze the short-run and long-run coefficient.

iii. It is used for smaller sample size.

Employing the ARDL bound test, the null hypothesis of absence of long-run relationship is accepted provided the calculated $F$-statistic is less than the critical value of the lower bound 1(0), while the null hypothesis is rejected provided the calculated $F$-statistic is more than the critical value of the upper bound 1(1). In a situation when the calculated $F$-statistic falls the critical value of the lower bound $1(0)$ and the upper bound 1(1), the result becomes inconclusive.

\section{Results and discussion}

\section{Stationarity test}

The result of the stationarity test is presented in Table 1 . The outcome of the test result revealed that $\log (\mathrm{AO}), \log$
(PRCI), $\log (\mathrm{PUBCI})$ and $\log (L)$ are stationary at first difference, while $\log (K)$ EXR and log (REXR) are stationary at level. This implies that the variables are integrated at both 1(1) and 1(0). Hence, the use of ARDL technique becomes appropriate. The study also employed the use of Bai-Perron test to capture the structural break in the variable. The outcome of the Bai-Perron test revealed that a structural break occurs in the dependent variable (AO).

\section{Estimation of the ARDL bound test}

The ARDL bound test for model 1 and 2 is presented in Table 2 . K shows the number of variables, computed as $k+1=n$, where $n$ represents the number of variables employed in the study. For both model, $k$ is computed as $k+1=6$, hence, $k=5$. The ARDL bound test showed that in both models, the calculated $F$-statistic is more than the critical value of the upper bound 1(1). This implies that the variables are cointegrated in each model.

\section{Short-run and long-run coefficient}

The short-run and long-run ARDL estimates for model 1 are reported in Table 3 . The outcome of the ARDL estimate showed that private capital inflows positively affect the country agricultural output in the short and long run. The implication of this is that government should attract more capital inflow to be directed to the

Table 1 Stationarity test

\begin{tabular}{lllll}
\hline KPSS (null: variable is stationary) & & $\begin{array}{l}\text { Structural } \\
\text { break }\end{array}$ \\
\cline { 1 - 4 } Variable & LM-statistic & $\begin{array}{l}\text { Critical } \\
\text { value } \\
\text { at } \mathbf{0 . 0 5} \\
\text { level }\end{array}$ & $\begin{array}{l}\text { Order } \\
\text { of integration }\end{array}$ & \\
\hline & 0.1153 & 0.146 & $1(1)$ & 1995 \\
\hline $\log (A O)$ & 0.463 & $1(1)$ & - \\
$\log (P R C l)$ & 0.2396 & 0.146 & $1(1)$ & - \\
$\log (P U B C I)$ & 0.1129 & 0.146 & $1(0)$ & - \\
$\log (K)$ & 0.1172 & 0.146 & $1(1)$ & - \\
$\log (L)$ & 0.0688 & 0.146 & $1(0)$ & - \\
$\log (R E X R)$ & 0.1091 & 0.146 & & \\
\hline
\end{tabular}

Table 2 ARDL bound test

\begin{tabular}{llllll}
\hline & \multicolumn{1}{c}{ F-statistics } & $\begin{array}{l}\text { Critical } \\
\text { value (\%) }\end{array}$ & $\begin{array}{l}\text { Lower } \\
\text { bound } \\
\text { value }\end{array}$ & $\begin{array}{l}\text { Upper } \\
\text { bound } \\
\text { value }\end{array}$ \\
\hline Model 1 & 5 & \multirow{2}{*}{9.64} & 1 & 2.82 & 4.21 \\
& & & 5 & 2.14 & 3.34 \\
Model 2 & 5 & \multirow{2}{*}{9.68} & 10 & 1.81 & 2.93 \\
& & & 1 & 2.82 & 4.21 \\
& & 5 & 2.14 & 3.34 \\
& & 10 & 1.81 & 2.93 \\
\hline
\end{tabular}


Table 3 ARDL short-run and long-run coefficient

\begin{tabular}{|c|c|c|c|c|c|}
\hline \multicolumn{3}{|l|}{ Model 1} & \multicolumn{3}{|l|}{ Model 2} \\
\hline \multicolumn{3}{|c|}{ Dependent variable log (AO) } & \multicolumn{3}{|c|}{ Dependent variable log (AO) } \\
\hline Variables & Short-run coefficient & Long-run coefficient & Variables & Short-run coefficient & Long-run coefficient \\
\hline $\log (\mathrm{PRCl})$ & $0.1294^{*}(0.0657)$ & $0.5319^{*}(0.2783)$ & $\log (\mathrm{PUBCI})$ & $0.2984 * * *(0.0916)$ & $0.5125^{* * *}(0.1019)$ \\
\hline $\log (\mathrm{INV})$ & $0.0105(0.0807)$ & $0.0432(0.316)$ & $\log (I N V)$ & $0.2811^{* * *}(0.0877)$ & $0.50066^{* * *}(0.0515)$ \\
\hline $\log ($ REXR) & $-0.0023(0.0959)$ & $-0.0093(0.3933)$ & $\log ($ REXR) & $-0.3169^{* * *}(0.1114)$ & $-0.0442(0.194)$ \\
\hline $\log (\mathrm{LAB})$ & $0.8066^{* *} 0.3294$ & $3.3158^{* *}(0.9409)$ & $\log (L A B)$ & $45.7638^{* *}(20.9303)$ & $0.1391(0.7866)$ \\
\hline Dummy & $0.1461(0.203)$ & 0.6009 (0.6659) & Dummy & $0.3218^{*}(0.1634)$ & $0.5798^{* *}(0.2689)$ \\
\hline $\mathrm{ECT}(-1)$ & $-0.2433^{*}(0.1254)$ & & $\mathrm{ECT}(-1)$ & $-0.5549^{* * *}(0.1294)$ & \\
\hline
\end{tabular}

$* * * * *,{ }^{*}$ indicates at $1 \%, 5 \%$ and $10 \%$ levels of significance, respectively. The figure in bracket represents standard errors

agricultural sector. The result further indicates that real effective exchange rate negatively affects the nation agricultural output in the short and long run. This implies that exchange rate depreciation would cause a decline in agricultural output. In addition, the result revealed that domestic investment has positively influenced agricultural output in the short and long run. The research output also indicates that labor positively affects agricultural output in the country. This implies that government should take advantage of the abundant labor force in the country in enhancing agricultural output in the country. The coefficient of the ECT $(-0.2433)$ is negative and significant. This signifies that in the following year, the deviation in agricultural output is corrected by $24.3 \%$, thus signifying that the whole system would be restored back to long-run equilibrium at the speed of $24.3 \%$.

From the model 2 results, it is revealed that public capital inflow (PUBCI) positively affects the nation agricultural output in the short and long run. The result also revealed that in the short and long run, exchange rate affects agricultural output negatively. In addition, the result showed that domestic investment has positively influenced agricultural output in the country. Moreover, the result indicates that labor force positively affects the country agricultural output. The coefficient of the ECT $(-0.5549)$ is negative and significant. This signifies that in the following year, the deviation in agricultural output is corrected by $55.49 \%$, thus signifying that the whole system would be restored back to long-run equilibrium at the speed of $55.49 \%$.

In summary, the ARDL estimate indicates that in the short and long run, both private capital inflow and public capital inflow have influenced the growth of agricultural output positively, while exchange rate depreciation would cause a decline in the country agricultural output in the short and long run.

\section{Diagnostic test}

Table $4 \mathrm{a}$ and $\mathrm{b}$ presents the result of the diagnostic test for model 1 and model 2. The outcome of the diagnostic test indicates that both models is free from serial correlation and heteroscedasticity given that the probability of the observed $\mathrm{R}$ square in each of the test is greater than $5 \%$.

\section{Conclusion}

Applying the ARDL technique, the study analyzed the effect of capital inflows and exchange rate on agricultural output in Nigeria between the periods 1981 and 2016. The study variables include agricultural output (AO), private capital inflow (PRCI), public capital inflow (PUBCI), investment (INV), labor $(L)$ and real effective exchange rate. The result of the stationarity test showed that some variables are stationary at level and first difference, i.e., the variables are integrated at both 1(1) and 1(0), thus justifying the use of ARDL technique. The ARDL bound test result indicates that the variables are cointegrated.

Findings from the research revealed that in the short run and long run, private capital inflow and public capital inflow positively affect agricultural output. The study also indicates that exchange rate depreciation would cause agricultural output to decline in the short and long run.

The theoretical implication of the study is that capital inflows into the country can boost the country agricultural sector by increasing the agricultural output of the country, eradicate poverty among the populace, and provide employment opportunities to the teeming youth. Furthermore, through capital inflows, the farmers can import the needed technology to improve efficiency in the sector and operates in large scale.

Consequently, the government should create an enabling and conducive environment to attract more capital inflows into the country to boost the agricultural sector and increased its output. Also, monetary authority should ensure the stability of the country's exchange rate 
Table 4 Diagnostic test

(a)

\begin{tabular}{|c|c|c|c|c|}
\hline & Model 1 & & & \\
\hline \multirow{2}{*}{$\begin{array}{l}\text { Breusch-Godfrey serial correlation } \\
\text { LM test }\end{array}$} & F-statistic & 2.1992 & Prob. $F(2,20)$ & 0.1545 \\
\hline & Obs* $R$-squared & 2.6972 & Prob. $x^{2}(2)$ & 0.1005 \\
\hline \multirow{3}{*}{$\begin{array}{l}\text { Breusch-Pagan-Godfrey heterosce- } \\
\text { dasticity test }\end{array}$} & F-statistic & 0.5332 & Prob. $F(9,22)$ & 0.7764 \\
\hline & Obs* $R$-squared & 3.7467 & Prob. $x^{2}(9)$ & 0.7109 \\
\hline & Scaled explained SS & 8.9167 & Prob. $x^{2}(9)$ & 0.1783 \\
\hline
\end{tabular}

(b)

\begin{tabular}{|c|c|c|c|c|}
\hline & Model 2 & & & \\
\hline \multirow{2}{*}{$\begin{array}{l}\text { Breusch-Godfrey serial correlation } \\
\text { LM test }\end{array}$} & F-statistic & 1.1644 & Prob. $F(2,20)$ & 0.3002 \\
\hline & Obs*R-squared & 2.055 & Prob. $x^{2}(2)$ & 0.1517 \\
\hline \multirow{3}{*}{$\begin{array}{l}\text { Breusch-Pagan-Godfrey Heteroske- } \\
\text { dasticity test }\end{array}$} & F-statistic & 1.4365 & Prob. $F(9,22)$ & 0.2644 \\
\hline & Obs ${ }^{*} R$-squared & 13.7156 & Prob. $x^{2}(9)$ & 0.2491 \\
\hline & Scaled explained SS & 5.0088 & Prob. $x^{2}(9)$ & 0.9307 \\
\hline
\end{tabular}

(naira), since exchange rate depreciation affects agricultural output negatively. Furthermore, there is the need for the harmonization of foreign capital inflow policy and monetary policy by the government, taking into consideration the optimal level of capital inflow that will not have a detrimental effect on exchange rate so as to ensure sustainable growth in agricultural output.

\section{Limitation and future directions}

The study is a single-country study; future studies can focus on the effect of capital inflows and exchange rate on agricultural output by employing cross-country data. Also, the dynamic interaction between capital inflows, exchange rate, and agricultural output can also be examined.

\section{Acknowledgements}

Not applicable.

\section{Authors' contributions}

$\mathrm{FI}$ and $\mathrm{AOE}$ both made substantial contributions to the manuscript in terms of conception, design, acquisition of data, analysis and interpretation of data. All authors read and approved the final manuscript.

\section{Funding}

The authors wish to state that no funding was obtained for this study.

\section{Availability of data and materials}

The datasets generated during the current study are available in Central Bank of Nigeria Statistical Bulletin 2017 and World Bank Development Indicator (WDI) 2017.

\section{Competing interests}

The authors declare that they have no competing interests.

\section{Author details}

1 Pan-Atlantic University, Km 52, Lekki-Epe Expressway, Ibeju-Lekki, Lagos, Nigeria. ${ }^{2}$ Federal University of Agriculture, Makurdi, Benue State, Nigeria.
Received: 20 August 2019 Accepted: 18 October 2019

Published online: 14 November 2019

\section{References}

1. Abdullahi H (2014) Macroeconomic policy and agricultural output in Nigeria: implications for food security. Am J Econ 4(2):99-113

2. Abro ZA, Alemu BA, Hanjra MA (2014) Policies for agricultural productivity growth and poverty reduction in rural Ethiopia. World Dev 59:461-474

3. Adegbite EO, Adetiloye KA (2013) Financial globalization and domestic investment in developing countries: evidence from Nigeria. Mediterr J Soc Sci 4(6):213

4. Adeola O, Ikpesu F (2016) An empirical investigation of the impact of bank lending on agricultural output in Nigeria: a vector autoregressive (VAR) approach. J Dev Areas 50(6):89-103

5. Ajuwon OS, Ogwumike FO (2013) Uncertainty and foreign direct investment: a case of agriculture in Nigeria. Mediterr J Soc Sci 4(1):155-165

6. Akpokodje G, Omojimite BU (2008) The effect of Aid flows on Nigeria's Agricultural Growth. Pak J Soc Sci 5(6):514-520

7. Anetor FO, Ogbechie C, Kelikume I, Ikpesu F (2016) Credit supply and agricultural production in Nigeria: a vector autoregressive (VAR) approach. J Econ Sustain Dev 7(2):131-143

8. Barrett K (2014) The effect of remittances on the real exchange rate: the case of Jamaica. Caribbean Centre for Money and Finance, West Indies

9. Bentzen J, Engsted T (2001) A revival of the autoregressive distributed lag model in estimating energy demand relationships. Energy 26(1):45-55

10. Chaudhuri S, Banerjee D (2010) FDI in agricultural land, welfare and unemployment in a developing economy. Res Econ 64(4):229-239

11. Christiaensen L, Todo Y (2014) Poverty reduction during the rural-urban transformation - the role of the missing middle. World Dev 63:43-58

12. Djokoto JG (2011) Inward foreign direct investment flows, growth, and agriculture in Ghana: a Granger causal analysis. Int J Econ Finance 3(6): 188

13. Djokoto JG (2012) Effects of foreign direct investment inflows into agriculture on food security in Ghana. J Econ Sustain Dev 3(2):81-92

14. Djokoto JG (2013) Openness and agricultural performance in Ghana. J Sci Technol (Ghana) 33(2):24-36

15. Epaphra M (2016) Foreign direct investment and sectoral performance in Tanzania. J Econ Polit Econ 3(4):670

16. Epaphra M, Mwakalasya AH (2017) Analysis of foreign direct investment, agricultural sector and economic growth in Tanzania. Mod Econ 8(01):111 
17. Gameli Djokoto J, Yao Srofenyoh F, Gidiglo K (2014) Domestic and foreign direct investment in Ghanaian agriculture. Agric Finance Rev 74(3):427-440

18. Ghatak S, Siddiki JU (2001) The use of the ARDL approach in estimating virtual exchange rates in India. J Appl Stat 28(5):573-583

19. Hallam D (2009) Foreign investment in developing country agriculture: issues, policy implications and international response. In: OECD Global Forum on International Investment, pp 1-9

20. Iddrisu AA, Immurana M, Halidu BO (2015) The impact of foreign direct investment (FDI) on the performance of the Agricultural Sector in Ghana. Int J Acad Res Bus Soc Sci 5(7):240-259

21. Issa $H$, Ouattara B (2008) Foreign aid flows and real exchange rate: evidence from Syria. J Econ Dev 33(1):133-146

22. Johansen S, Juselius K (1990) Maximum likelihood estimation and inference on cointegration - with applications to the demand for money. Oxford Bull Econ Stat 52(2):169-210

23. Juselius K, Møller NF, Tarp F (2014) The long-run impact of foreign aid in 36 African countries: insights from Multivariate Time Series Analysis. Oxford Bull Econ Stat 76(2):153-184

24. Kareem R, Bakare H, Raheem K, Ologunla S, Alawode O, Ademoyewa $G$ (2013) Analysis of factors influencing agricultural output in Nigeria: macro-economic Perspectives. Am J Bus Econ Manag 1:9-15

25. Larson DW, Vogel RC (1986) Have foreign capital inflows adversely affected agriculture in developing countries? A paper presented at the Annual Meeting of American Agricultural Economics Association (AAEA), Reno, Nevada

26. Massoud N (2008) FDI and growth in emerging markets: does the sectoral distribution matter-the case of Egypt (pp 1-39). EMG Working Paper Series, no.WP-EMG-05-2008

27. Modarress B, Ansari A, Thies E (2014) The impact of technology transfer through foreign direct investment in developing nations: a case study in the United Arab Emirates. Int J Econ Finance 6(7):108

28. Msuya $E$ (2007) The impact of foreign direct investment on agricultural productivity and poverty reduction in Tanzania. Research Paper. Kyoto University, Japan

29. Nkoro E, Uko AK (2016) Autoregressive distributed lag (ARDL) cointegration technique: application and interpretation. J Stat Econ Methods 5(4):63-91

30. Obadan MI (2013) Coping with capital flow volatility: policy consideration for Nigeria. Cent Bank Niger 51(4):177
31. Obansa SAJ, Maduekwe IM (2013) Agriculture financing and economic growth in Nigeria. Eur Scientific J ESJ 9(1)

32. Oloyede BB (2014) Impact of foreign direct investment on agricultural sector development in Nigeria, (1981-2012). Kuwait Chap Arab J Bus Manag Rev 3(12):14

33. Oyinbo O, Abraham F, Rekwot GZ (2014) Nexus of exchange rate deregulation and agricultural share of gross domestic product in Nigeria. CBN J Appl Stat 5(2):49-64

34. Reinhart M (2005) Some perspective on capital flows to emerging market economies. NBER Reporter: research summary

35. Sattaphon W (2006) Do Japanese foreign direct investment and trade stimulate agricultural growth in East Asia? Panel cointegration analysis. In: International association of agricultural economists conference

36. Simplice A (2014) Development thresholds of foreign aid effectiveness in Africa. Int J Soc Econ 41(11):1131-1155

37. Tahir M, Khan I, Shah AM (2015) Foreign remittances, foreign direct investment, foreign imports and economic growth in Pakistan: a time series analysis. Arab Econ Bus J 10(2):82-89

38. Wondemu KA, Potts DJ (2016) The impact of the real exchange rate changes on export performance in Tanzania and Ethiopia. African Development Bank Working Paper Series, No. 240

39. Yaqub JO (2013) The impact of exchange rate changes on disaggregated agricultural output in Nigeria: a two-stage-least-squares approach. Int J Econ Sci App Res 6(1):75-89

40. Yusuf KU (2015) The impact of foreign direct investment on agricultural output of Nigeria (Master dissertation, Universiti Utara Malaysia)

41. Yusuff MA, Afolayan OT, Adamu AM (2015) Analysis of foreign direct investment on agricultural sector and its contribution to GDP in Nigeria. $J$ Emerg Trends Econ Manag Sci 7(2):94-100

42. Taurai Z (2014) Foreign direct investment (FDI) and agricultural growth in Zimbabwe. (Doctoral dissertation, Midlands State University)

43. Zingwena T (2014) Foreign direct investment (FDI) and agricultural growth in Zimbabwe. A BSc thesis submittedto the department of agricultural economics and development. State University, Zimbabwe, Midlands

\section{Publisher's Note}

Springer Nature remains neutral with regard to jurisdictional claims in published maps and institutional affiliations.

\section{Submit your manuscript to a SpringerOpen ${ }^{\circ}$ journal and benefit from:}

- Convenient online submission

- Rigorous peer review

- Open access: articles freely available online

- High visibility within the field

Retaining the copyright to your article

Submit your next manuscript at springeropen.com 